\title{
Studies on Path Coefficient Analysis in Maize (Zea mays L.) for Grain Yield and Its Attributes
}

\author{
Dan Singh Jakhar*, Rajesh Singh and Amit Kumar \\ Department of Genetics and Plant Breeding, Institute of Agricultural Sciences, \\ Banaras Hindu University, Varanasi-221005, UP, India \\ *Corresponding author
}

\begin{tabular}{|c|c|}
\hline & A B S T R A C T \\
\hline $\begin{array}{l}\text { Ke y w o r d s } \\
\text { Path coefficient } \\
\text { analysis, Grain } \\
\text { yield, Zea mays L. }\end{array}$ & $\begin{array}{l}\text { The efficiency of a breeding programme depends mainly on the direction and } \\
\text { magnitude of the association between yield and its components and also the } \\
\text { relative importance of each factor involved in contributing to grain yield. The path } \\
\text { analysis provides an effective measure of direct and indirect causes of association } \\
\text { and depicts the relative importance of each factor involved in contributing to the }\end{array}$ \\
\hline Article Info & $\begin{array}{l}\text { final product. Direct and positive effect on yield was exhibited by days to } 75 \% \\
\text { brown husk, tassel length, cob length without husk, days to } 50 \% \text { tasselling, leaf }\end{array}$ \\
\hline $\begin{array}{l}\text { Accepted: } \\
\text { 08 March } 2017 \\
\text { Available Online: } \\
10 \text { April } 2017\end{array}$ & $\begin{array}{l}\text { width, plant height, } 100 \text { seed weight, cob length with husk, cob diameter } \\
\text { indicating the effectiveness of direct selection, where as direct and negative effects } \\
\text { were exhibited by days to } 50 \% \text { silking and ear height indicating the effectiveness } \\
\text { of indirect selection. }\end{array}$ \\
\hline
\end{tabular}

\section{Introduction}

Globally Maize (Zea mays L.) is one of the staple food crops. In world, it ranks second to wheat in production with milled rice occupying the third position in the world (Downswell et al., 1996). Maize is a versatile crop grown over a range of agro climatic zones. In fact the suitability of maize to diverse environments is unmatched by any other crop. It is grown from $58^{\circ} \mathrm{N}$ to $40^{\circ} \mathrm{S}$, from below sea level to altitudes higher than $3000 \mathrm{~m}$, and in areas with $250 \mathrm{~mm}$ to more than $5000 \mathrm{~mm}$ of rainfall per year (Downswell et al., 1996) and with a growing cycle ranging from 3 to 13 months. However the major maize production areas are located in temperate regions of the globe. The United
States, China, Brazil and Mexico account for $70 \%$ of global production. India has $5 \%$ of corn acreage and contributes $2 \%$ of world production. In India maize crop stand up as the third cash crop after wheat and rice. The production and consumption of maize have been rising frequently in India. Maize production in the country has taken a hit in 2015-16 due to two continuous years of below normal monsoon rains, followed by drought. India received $14 \%$ below normal southwest monsoon rains in 2015, and rainfall was $12 \%$ below normal in 2014. Around 11 states have declared drought like situations in 266 districts during 2015 -16. India's Kharif maize acreage was at 1.15 million hectares as of 
23rd June 2016, down 12\% from a year-ago level, according to data from the agriculture ministry. Maize is not only used as human food and animal feed, but is as well commonly used in several other industries as a raw material. The path analysis first suggested by Wright (1921) and later illustrated by Dewey and Lu (1959) provides an effective measure of direct and indirect causes of association and depicts the relative importance of each factor involved in contributing to the final product.

\section{Materials and Methods}

\section{Experimental material}

The experimental materials consisted of 30 accessions of maize (Zea mays L.) obtained from the my supervisor Prof. Rajesh Singh, Maize Breeder in Department of Genetics and Plant Breeding, Institute of Agricultural Sciences, Banaras Hindu University, Varanasi.

\section{Experimental design and land preparation}

The experiment was laid out in randomized block design. The field was divided into three homogeneous replication blocks. Thirty genotypes were randomly planted in three replications. Each entry was represented by a double row of $4 \mathrm{~m}$ length spaced at $75 \mathrm{~cm}$ between the rows and $20 \mathrm{~cm}$ between the plants within the rows. A uniform piece of land was selected for laying out the experiment. The land was brought to the fine tilth by ploughing and harrowing.

\section{Data collection}

Observations on following twelve characters were recorded on five randomly selected plants from each plot in each replication. These plants were tagged before tasseling. The data were recorded on plant height $(\mathrm{cm})$, days to $50 \%$ tasselling, days to $50 \%$ silking, days to $75 \%$ brown husk, ear height $(\mathrm{cm})$, leaf width $(\mathrm{cm})$, tassel length $(\mathrm{cm})$, cob length with husk $(\mathrm{cm})$, cob length without husk $(\mathrm{cm})$, cob diameter $(\mathrm{cm}), 100$ seed weight $(\mathrm{g})$, and grain yield per plant $(\mathrm{g})$.

\section{Statistical analysis}

\section{Path coefficient analysis}

To establish a cause and effect relationship the first step used was to partition genotypic and phenotypic correlation coefficient into direct and indirect effects by path analysis as suggested by Dewey and Lu (1959) and developed by Wright (1921).

The second step in path analysis is to prepare path diagram based on cause and effect relationship. In the present study, path diagram was prepared by taking yield as the effect i.e. function of various components like $\mathrm{X}_{1}, \mathrm{X}_{2}, \mathrm{X}_{3}$ and these component showed following type of association with each other.

In path diagram the yield is the result of $X_{1}$, $\mathrm{X}_{2}, \mathrm{X}_{3} \ldots . \mathrm{Xn}$ and some other undefined factors designated by $\mathrm{R}$. The double arrow lines indicated mutual association as measured by correlation coefficient. The single arrow represents direct influence as measured by path coefficient $\mathrm{P}_{\mathrm{ij}}$.

Path coefficients were obtained by solving a set of simultaneous equation of the form as per Dewey and Lu (1959).

$r_{n y}=P_{n y}+r_{n 2} P_{2 y}+r_{n 3} P_{3 y}+\ldots \ldots \ldots \ldots \ldots$

Where,

$\mathrm{r}_{\mathrm{ny}}=$ represents the correlation between one component and yield

$\mathrm{P}_{\mathrm{ny}}=$ represents path coefficient between that character and yield

$\mathrm{r}_{\mathrm{n} 2}=$ represents correlation between that character and each of the other components in turn. 


\section{Results and Discussion}

Path-coefficient analysis was studied at phenotypic level considering grain yield as dependent character. The independent characters were plant height $(\mathrm{cm})$, days to $50 \%$ tasselling, days to $50 \%$ silking, days to $75 \%$ brown husk, ear height $(\mathrm{cm})$, leaf width $(\mathrm{cm})$, tassel length $(\mathrm{cm})$, cob length with husk $(\mathrm{cm})$, cob length without husk $(\mathrm{cm})$, cob diameter $(\mathrm{cm}), 100$ seed weight $(\mathrm{g})$, and grain yield per plant $(\mathrm{g})$. The phenotypic correlation was partitioned into direct and indirect effects on seed yield (Figure 1) and the data is presented in (Table 1).

The highest positive and direct effect was found for days to $75 \%$ brown husk (0.3827) followed by tassel length (0.2268), cob length without husk (0.2258), days to $50 \%$ tasseling $(0.1767)$ and leaf width (0.1723). The negative and direct effect was found for days to $50 \%$ silking $(-0.3724)$ and ear height (0.092).

The plant height showed highly positive indirect effect for ear height (0.1421) followed by leaf width $(0.7930)$, cob length with husk (0.0249) and tassel length (0.0245).

Days to $50 \%$ tasseling was found highly positive indirect effect to days to $50 \%$ silking (0.1527) followed by days to $75 \%$ brown husk (0.1343) and leaf width (0.0252). Whereas negative indirect effect for 100 seed weight $(-0.0212)$ followed by tassel length ($0.0090)$ and cob length with husk (-0.0032).

Days to $50 \%$ silking showed highly positive indirect effect for 100 seed weight $(0.0518)$ and tassel length (0.0011).

Whereas, it has found negative indirect effect for days to $75 \%$ brown husk (-0.3255) followed by days to $50 \%$ tasseling $(-0.3218)$ and leaf width (-0.0531). Days to $75 \%$ brown husk was found positively indirect effect to days to $50 \%$ silking $(0.3345)$ followed by days to $50 \%$ tasseling (0.2909) and leaf width (0.0686). Negative indirect effect was found to 100 seed weight $(-0.0549)$ and tassel length $(-0.0054)$.

The ear height showed highly negative indirect effect for plant height $(-0.0852)$ followed by leaf width $(-0.0467)$ and cob diameter (-0.0206).

The leaf width was found highly positive indirect effect to plant height (0.0891) followed by ear height $(0.0875)$ and tassel length (0.0384). Whereas, negatively indirect effect was found for cob diameter (-0.0018).

Tassel length showed highly positive indirect effect for leaf width (0.0505) followed by plant height (0.0362) and cob length with husk (0.0318) and negative indirect effect was found for days to $50 \%$ tasseling $(-0.0115)$ followed by days to $75 \%$ brown husk $(-0.0032)$ and days to $50 \%$ silking $(-0.0007)$.

The cob length with husk was found highly positive indirect effect to cob length without husk (0.0460) followed by 100 seed weight $(0.0322)$ and days to $75 \%$ brown husk (0.0174).

Whereas, negatively indirect effect was found to days to $50 \%$ tasseling $(-0.0018)$.

The cob length without husk showed highly positive indirect effect for cob length with husk (0.1069) followed by 100 seed weight (0.0789) and ear height (0.0357).

The cob diameter showed highly positive indirect effect for ear height (0.0165) followed by cob length with husk (0.0125) and plant height (0.009) and high negative indirect effect was found for 100 seed weight $(-0.0063)$ and leaf width $(-0.0008)$. 
Table.1 Phenotypic path coefficient analysis indicating direct and indirect effects of component characters on grain yield in 30 genotypes of maize

\begin{tabular}{lcccccccccccc}
\hline Characters & PH & DTT & DTS & DBH & EH & LW & TL & CLWH & CLWOH & CD & 100 SW & GY \\
\hline PH & $\mathbf{0 . 1 5 3 3}$ & 0.0049 & 0.0054 & 0.0177 & 0.1421 & 0.0793 & 0.0245 & 0.0249 & 0.0205 & 0.0187 & 0.0064 & 0.2892 \\
DTT & 0.0057 & $\mathbf{0 . 1 7 6 7}$ & 0.1527 & 0.1343 & 0.0114 & 0.0252 & -0.0090 & -0.0032 & 0.0154 & 0.0143 & -0.0212 & 0.1698 \\
DTS & -0.0132 & -0.3218 & $\mathbf{- 0 . 3 7 2 4}$ & -0.3255 & -0.0136 & -0.0531 & 0.0011 & -0.0213 & -0.0383 & -0.0423 & 0.0518 & 0.1640 \\
DBH & 0.0442 & 0.2909 & 0.3345 & $\mathbf{0 . 3 8 2 7}$ & 0.0438 & 0.0686 & -0.0054 & 0.0685 & 0.0391 & 0.0448 & -0.0549 & 0.2613 \\
EH & -0.0852 & -0.0059 & -0.0034 & -0.0105 & $\mathbf{- 0 . 0 9 2 0}$ & -0.0467 & -0.0101 & -0.0134 & -0.0145 & -0.0206 & -0.0042 & 0.2752 \\
LW & 0.0891 & 0.0245 & 0.0246 & 0.0309 & 0.0875 & $\mathbf{0 . 1 7 2 3}$ & 0.0384 & 0.0110 & 0.0154 & -0.0018 & 0.0076 & 0.3261 \\
TL & 0.0362 & -0.0115 & -0.0007 & -0.0032 & 0.0250 & 0.0505 & $\mathbf{0 . 2 2 6 8}$ & 0.0318 & 0.0056 & 0.0162 & 0.0272 & 0.3027 \\
CLWH & 0.0158 & -0.0018 & 0.0056 & 0.0174 & 0.0142 & 0.0062 & 0.0136 & $\mathbf{0 . 0 9 7 2}$ & 0.0460 & 0.0164 & 0.0322 & 0.3476 \\
CLWOH & 0.0302 & 0.0196 & 0.0232 & 0.0231 & 0.0357 & 0.0202 & 0.0056 & 0.1069 & $\mathbf{0 . 2 2 5 8}$ & 0.0010 & 0.0789 & 0.3500 \\
CD & 0.0090 & 0.0060 & 0.0084 & 0.0086 & 0.0165 & -0.0008 & 0.0053 & 0.0125 & 0.0003 & $\mathbf{0 . 0 7 3 8}$ & -0.0063 & 0.1119 \\
100 SW & 0.0041 & -0.0119 & -0.0138 & -0.0142 & 0.0046 & 0.0044 & 0.0119 & 0.0329 & 0.0346 & -0.0084 & $\mathbf{0 . 0 9 9 1}$ & 0.2166 \\
\hline
\end{tabular}

\section{RESIDUAL EFFECT $=0.8029$}

Where PH $(\mathrm{cm})=$ plant height, DTT $(50 \%)=$ days to 50\% tasseling, DTS $(50 \%)=$ days to $50 \%$ silking, DBH $(75 \%)=$ days to $75 \%$ brown husk, EH $(\mathrm{cm})=$ ear height, $\mathrm{TL}(\mathrm{cm})=$ tassel length, $\mathrm{CLWH}(\mathrm{cm})=$ cob length with husk, $\mathrm{CLWOH}(\mathrm{cm})=$ cob length without husk, $\mathrm{CD}(\mathrm{cm})=\mathrm{cob}$ diameter, $\mathrm{KRC}=$ No. of kernel per cob, $\mathrm{KR}=$ No. of kernel per row, $100 \mathrm{SW}(\mathrm{g})=100$ seed weight, $\mathrm{GYP}=$ yield per plant. 
Figure.1 Phenotypic path diagram for grain yield and its attributes

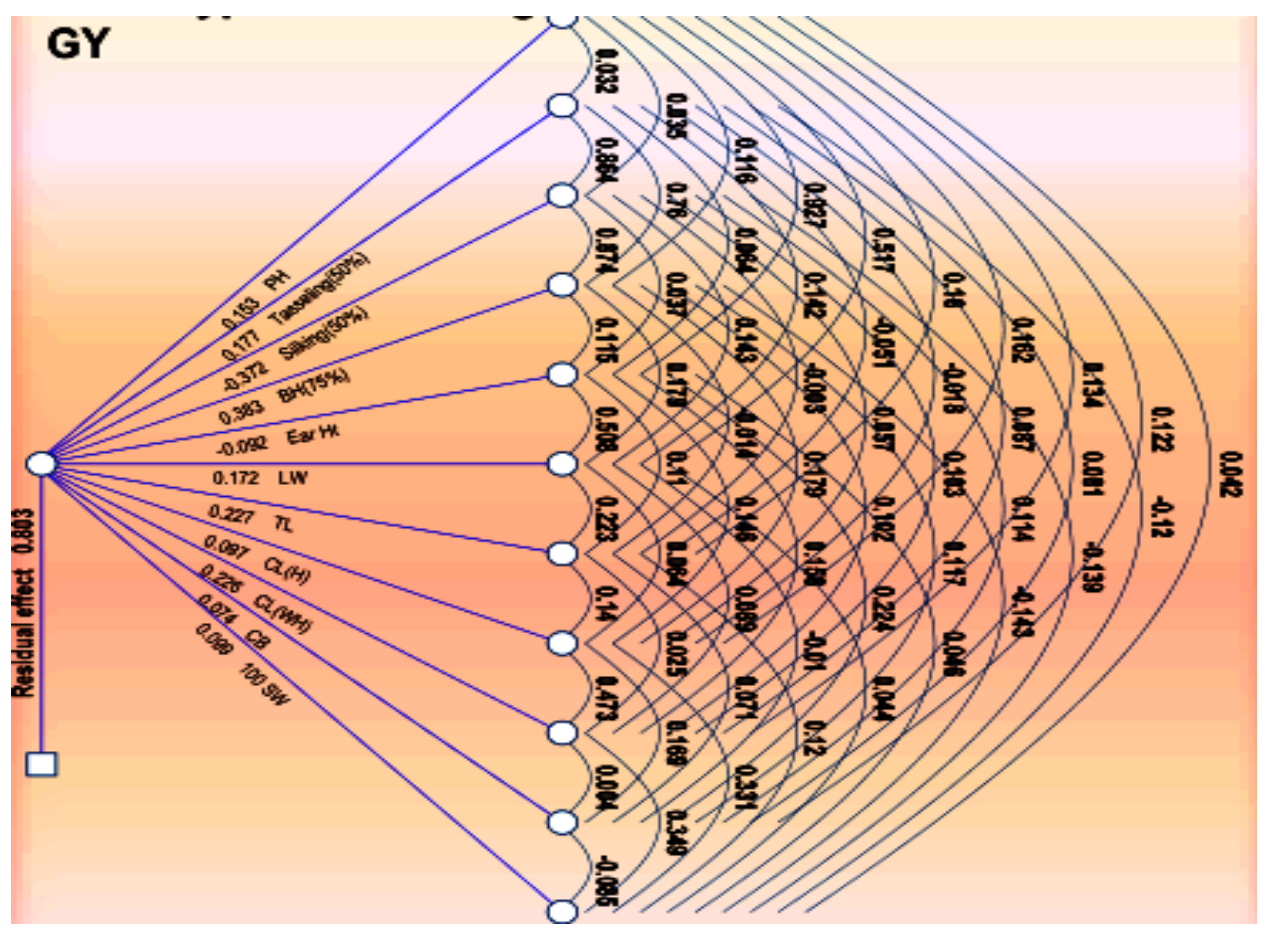

The 100 seed weight showed highly positive indirect effect for cob length without husk (0.0346) followed by cob length with husk $(0.0329)$ and tassel length (0.0119) and highly negative indirect effect was found for days to $75 \%$ brown husk $(-0.0142)$ followed by days to $50 \%$ silking $(-0.0138)$ and days to $50 \%$ tasseling (-0.0119).

The estimation of correlation indicates only the extent and nature of association between yield and its attributes, but does not show the direct and indirect effects of different yield attributes on yield per se. Grain yield is dependent on several characters which are mutually associated; these will in turn impair the true association exiting between a component and grain yield. A change in any one component is likely to disturb the whole network of cause and effect. Thus, each component has two paths of action viz., the direct influence on grain yield, indirect effect through components which are not revealed from the correlation studies. The highly positive and direct effect on yield was exhibited by days to $75 \%$ brown husk followed by tassel length, cob length without husk, days to 50\% tasselling, leaf width, plant height, 100 seed weight, cob length with husk, cob diameter indicating the effectiveness of direct selection, where as direct and negative effects were exhibited by days to $50 \%$ silking and ear height indicating the effectiveness of indirect selection. These findings were in agreement with reports of Sharma and Kumar (1987), Alok kumar et al., (1999), Venugopal et al., (2003) for plant height and ear length; Kumar et al., (2006) for days to 50\% tasseling; Venugopal (2003), Kumar et al., (2006) and Brar et al., (2008) for ear height; Kumar et al., (2006), Shakoor et al., (2007), Sofi and Rather (2007) and Saidaiah et al., (2008) for 100 grain weight.

\section{References}

Alok Kumar, Gangashetti, M.G. and Dahia, A. 1999. Analysis of direct and indirect effects for quantitative traits in diallel crosses of maize (Zea mays 
L.). Annals of Biology, Ludhiana 15(2):173-176.

Brar, S.P.S, Chawla, J.S and Singh, P. 2008. Studies on different selection indices and path analysis in maize (Zea mays L.). Crop Improvement 35(1): 16-19.

Dewey, D.R. and Lu, H.K. 1959. A correletion and path coefficient analysis of components of creasted wheat grass and seed production. Agronomy Journal 51: 515-518.

Downsell, C.R., Paliwal, R.L. and Cantrell, R.P. 1996. Maize in the third world. West view press, pp. 1-37.

Kumar, S., Shahi, J.P., Singh, J. and Singh, S.P. 2006. Correlation and path analysis inearly generation inbreds of maize (Zea mays L.). Crop Improvement 33(2): 156-160.

Saidaiah, P., Satyanarayana, E. and Kumar, S.S. 2008. Association and path coefficient analysis in maize (Zea mays L.). Agricultural Science Digest 28: 79-83.

Shakoor, M.S., Muhammadand, A. and Hussain, A. 2007. Correlation and path analysis studies in maize double crosses. Pak. J. Agri. Sci., Vol. 44(2): 213-216.

Sharma, R.K. and Kumar, S. 1987. Association analysis for grain yield and some quantitative traits in pop corn. Crop Improvement. 14: 201-204.

Sofi, P.A. and Rather, A.G. 2007. Studies on genetic variability, correlation and path analysis in maize (Zea mays L.). Maize-Genetics-CooperationNewsletter (81): 26-27.

Venugopal, M., Ansari, N.A. and Rajanikanth, T. 2003. Correlation and path analysis inmaize (Zea mays L.). Crop Res., Hisar, 25(3): 525-529.

Wright, S. 1921. Correlation and causation. J. Agric. Res., 20: 557-587.

\section{How to cite this article:}

Dan Singh Jakhar, Rajesh Singh and Amit Kumar. 2017. Studies on Path Coefficient Analysis in Maize (Zea mays L.) for Grain Yield and Its Attributes. Int.J.Curr.Microbiol.App.Sci. 6(4): 2851-2856. doi: https://doi.org/10.20546/ijcmas.2017.604.327 